\title{
Comparison of infection by Brucella spp. in free-ranging and captive wild animals from São Paulo State, Brazil
}

Antunes JMAP (1), Machado GP (1), Costa LF (1), Fornazari F (1), Cipriano JRB (1), Appolinário CM (1), Allendorf SD (1), Bagagli E (2), Teixeira CR (3), Megid J (1)

(1) Department of Veterinary Hygiene and Public Health, School of Veterinary Medicine and Animal Husbandry, São Paulo State University (UNESP - Univ Estadual Paulista), Botucatu, São Paulo State, Brazil; (2) Department of Microbiology and Immunology, Botucatu Biosciences Institute, São Paulo State University (UNESP - Univ Estadual Paulista), Botucatu, São Paulo State, Brazil; (3) Center of Medicine and Research of Wild Animals, CEMPAS, School of Veterinary Medicine and Animal Husbandry, São Paulo State University (UNESP - Univ Estadual Paulista), Botucatu, São Paulo State, Brazil.

\begin{abstract}
The aim of the current study was to evaluate the infection rate by Brucella spp. in wild and in captive animals. Serum samples from 121 animals (94 free-ranging and 27 captive) of different mammal species were evaluated. Sera were submitted to rose Bengal test (RBT) for screening and serum agglutination tests (SAT) and 2-mercaptoethanol test (2-ME) for confirmatory results. Nine animals (five free-ranging and four captive) tested positive in RBT, but negative in the confirmatory tests. Several domestic animal diseases that have control programs are not focused on wild reservoirs, such as brucellosis in Brazil. The study of new reservoirs in wildlife is essential to prevent emerging diseases.
\end{abstract}

Key words: brucellosis, wildlife, zoonosis.

The key for controlling several zoonoses including brucellosis - is to focus on animal reservoirs (1). Wild animals as reservoirs of classical and emerging zoonoses persist in numerous countries and substantially hinder the efforts for controlling these infections (2). The fast-growing demand for milk and meat in urban centers has provoked the intensification of livestock production in periurban areas which, in turn, has increased the risk for zoonosis transmission (3).

The bacteria of the genus Brucella spp. are generalists when it comes to hosts, including wild animals (4). Brucellosis has been reported in marsupials, peccary, swine, camelids, cattle, pinnipeds and cetaceans (5-10). It is suggested that $B$. abortus infection occurs by eating carcasses, placental or fetal remnants of diseased animals (11). Abortions, orchitis, epididymitis and infertility are the main clinical manifestations in wild mammals (12). Infectious pathogens affect not only public health but also the economy, and wildlife conservation. Wild animals that are treated as exotic pets pose a risk to public health from exposure to zoonosis (13). Wildlife can become a new source of infection and re-contaminate domestic animals, as in the case of domestic pigs infected with brucellosis by wild boars in Europe (14). This study aimed to detect the infection rate by Brucella spp. in serum samples of free-ranging and captive wild animals.

Serum samples of 121 animals attended at the Center of Medicine and Research of Wild Animals, CEMPAS, UNESP, Botucatu, Brazil, were collected. The animals were both captive (from zoos or rehabilitation centers) and freeranging, found in localities adjacent to the municipality of Botucatu (22 $\left.53^{\prime} \mathrm{S} 48^{\circ} 26^{\prime} \mathrm{W}\right)$. Of the 121 samples collected from 2006 to 2009,94 belonged to free-ranging animals and 27 to captive ones (Table 1). The samples were serologically analyzed for Brucella spp. infection according to 
the National Program for Control and Eradication of Brucellosis and Tuberculosis (PNCEBT) of the Brazilian Ministry of Agriculture Livestock and Food Supply (MAPA) (15).

The serum samples were first evaluated by the screening test (RBT) and if they were considered reagent, they were then submitted to the confirmatory tests (tube agglutination test - TAT, and 2-mercaptoethanol test - 2-ME). Analysis of the data included calculation of statistical rates. The hypothesis was that free-ranging animals could have a higher frequency of infection than captive animals. Statistical analyses were performed in $2 \times 2$ small table [origin: (free-

Table 1. Serological results for Brucella spp. infection in free-ranging and captive wild animals from São Paulo state, Brazil

\begin{tabular}{|c|c|c|c|c|c|}
\hline Species & $\begin{array}{l}\text { Free-ranging } \\
(\mathrm{FR})^{*}\end{array}$ & $\begin{array}{l}\text { Captivity } \\
\text { (C) }\end{array}$ & RB & SAT & 2-ME \\
\hline Lion (Panthera leo) & 0 & 2 & $\mathrm{R}(1 \mathrm{C})$ & $\mathrm{N}$ & $\mathrm{N}$ \\
\hline Jaguarundi (Puma yagouaroundi) & 1 & 0 & NR & $\mathrm{N}$ & $\mathrm{N}$ \\
\hline Tiger (Panthera tigris) & 0 & 1 & NR & $\mathrm{N}$ & $\mathrm{N}$ \\
\hline Porcupine (Sphiggurus spp.) & 2 & 0 & NR & $\mathrm{N}$ & $\mathrm{N}$ \\
\hline Coati (Nasua nasua) & 3 & 2 & NR & $\mathrm{N}$ & $\mathrm{N}$ \\
\hline Patas monkey (Erythrocebus pata) & 0 & 2 & NR & $\mathrm{N}$ & $\mathrm{N}$ \\
\hline Maned wolf (Chrysocyon brachyurus) & 3 & 3 & $\mathrm{R}(1 \mathrm{C})$ & $\mathrm{N}$ & $\mathrm{N}$ \\
\hline Tufted Capuchin (Cebus apella) & 0 & 2 & NR & $\mathrm{N}$ & $\mathrm{N}$ \\
\hline Mandrill (Mandrillus sphinx) & 0 & 1 & NR & $\mathrm{N}$ & $\mathrm{N}$ \\
\hline Capybara (Hydrochoerus hidrochaeris) & 1 & 0 & NR & $\mathrm{N}$ & $\mathrm{N}$ \\
\hline Lowland paca (Cuniculus paca) & 2 & 6 & $\begin{array}{l}\mathrm{R}(1 \mathrm{FR} \text { and } \\
1 \mathrm{C})\end{array}$ & $\mathrm{N}$ & $\mathrm{N}$ \\
\hline Crab-eating fox (Cerdocyon thous) & 3 & 1 & NR & $\mathrm{N}$ & $\mathrm{N}$ \\
\hline Hoary fox (Lycalopex vetulus) & 1 & 1 & $\mathrm{R}(1 \mathrm{C})$ & $\mathrm{N}$ & $\mathrm{N}$ \\
\hline Brown howler monkey (Alouatta guariba) & 0 & 3 & NR & $\mathrm{N}$ & $\mathrm{N}$ \\
\hline Jaguar (Panthera onca) & 0 & 1 & NR & $\mathrm{N}$ & $\mathrm{N}$ \\
\hline White-eared opossum (D. albiventris) & 50 & 0 & $\mathrm{R}(3 \mathrm{FR})$ & $\mathrm{N}$ & $\mathrm{N}$ \\
\hline Gray brocket (Mazama gouazoubira) & 3 & 0 & NR & $\mathrm{N}$ & $\mathrm{N}$ \\
\hline European hare (Lepus europaeus) & 2 & 0 & NR & $\mathrm{N}$ & $\mathrm{N}$ \\
\hline Chimpanzee (Pan troglodytes) & 0 & 1 & NR & $\mathrm{N}$ & $\mathrm{N}$ \\
\hline Lesser anteater (Tamandua tetradactyla) & 1 & 0 & $\mathrm{R}(1 \mathrm{FR})$ & $\mathrm{N}$ & $\mathrm{N}$ \\
\hline $\begin{array}{c}\text { South African porcupine (Hystrix } \\
\text { africaeaustralis) }\end{array}$ & 0 & 1 & NR & $\mathrm{N}$ & $\mathrm{N}$ \\
\hline Nutria (Myocastor coypus) & 1 & 0 & NR & $\mathrm{N}$ & $\mathrm{N}$ \\
\hline $\begin{array}{l}\text { Greater naked tailed armadillo (Cabassous } \\
\text { tatouay) }\end{array}$ & 1 & 0 & NR & $\mathrm{N}$ & $\mathrm{N}$ \\
\hline $\begin{array}{c}\text { Nine-banded armadillo (Dasypus } \\
\text { novemcinctus) }\end{array}$ & 17 & 0 & NR & $\mathrm{N}$ & $\mathrm{N}$ \\
\hline $\begin{array}{c}\text { Six-banded armadillo (Euphractus } \\
\text { sexcinctus) }\end{array}$ & 3 & 0 & NR & $\mathrm{N}$ & $\mathrm{N}$ \\
\hline Total & 94 & 27 & & & \\
\hline
\end{tabular}

RB: rose Bengal; SAT: serum agglutination test; 2-ME: 2 mercaptoethanol test; R: reagent; NR: not reagent; P: positive; $\mathrm{N}$ : negative.

* OR: $3.23 ; 95 \% \mathrm{Cl}: 0.72-13.80 ; p>0.05$. 
ranging animals or captive animals) and RBT (positive or negative)], and submitted to chisquare analysis, and Fisher's exact test $(p \leq 0.05)$.

As displayed in Table 1, nine animals (five free-ranging and four captive) were positive for RBT, but none remained positive in the confirmatory tests. In the current study, no significant association between origin and RBT was observed (OR: 3.23; 95\%CI: 0.72-13.80; $p>$ 0.05). Fisher's exact test suggested that the origin of the animals is not significant for the source of infection.

The serological method employed in the present work is recommended by MAPA and is also utilized in serological surveys in wild animals (15-17). Serology is a standard technique for the epidemiological surveillance of brucellosis; however, cross-reactions between Brucella species and other gram-negative bacteria are a major problem of serological assays (18). The source of antigenic cross-reactions is the O-chain of the smooth lipopolysaccharide (S-LPS) present on the surface of the bacterial cell, which shows great similarity in smooth Brucella spp. False-positive serological results due only to Yersinia enterocolitica O:9 affect up to $15 \%$ of the cattle herds in regions free from brucellosis. However, there are no reports of $Y$. enterocolitica infection on wildlife species analyzed in this study. False-negative results have also been observed in serological diagnosis of brucellosis (19). They occur mostly due to the fact that the antibody response depends on the stage of infection during sample collection. Detectable amounts of antibodies are not recorded in the first 12 to 16 days after artificial inoculation of goats with Brucella abortus (20). On the other hand, when the disease becomes chronic, the antibody titer can drop to undetectable levels, which is the case of intracellular organisms such as Brucella spp. (20).

The results of serology in wild animals are controversial. Absence of positivity in experimental infection of opossums (D. virginiana) was previously reported (11). In the present study, the majority of the samples (52\%) were from whiteeared opossums (Didelphis albiventris), resulting in an underestimated prevalence of brucellosis in this animals. However, in opossums, we suggest a direct investigation of brucellosis in reproductive organs. In Austria, European hares (Lepus europaeus) are considered a source of human brucellosis while in Switzerland the disease is responsible for the declining population of hares $(21,22)$. Although this hare species is exotic, there are no reports of brucellosis infections in hares in Brazil, and the number of such animals captured in this study was small. There are studies on Brucella spp. microbiological isolation in buffalo (Bubalus bubalis), fox (Dusicyon gymnocercus antiquus), gray weasel (Didelphis marsupialis), capybara (Hydrochoerus hydroachaeris) and ferret (Galictis furax huranox) (23). In other species analyzed in the present study, there were no observed cases of brucellosis.

The present work reports for the first time serological positive results of Brucella spp. infection by RBT test in lions (Pantheraleo), maned wolves (Chrysocyon brachyurus), lowland pacas (Cuniculus paca), hoary foxes (Lycalopex vetulus), white-eared opossums (Didelphis albiventris), and lesser anteaters (Tamandua tetradactyla). From the 121 animals tested, $7.43 \%$ were positive by RBT. According to Lage et al. (15), brucellosis in Brazil ranged from 4 to $5 \%$ in bovines, and exploratory surveys are currently being carried out in most Brazilian states. According to MAPA, there are no specific tests recommended for wildlife. However, the methods employed in the present study were previously utilized in studies involving wild animals (17-20, 23). Consequently, there are no data available about the sensitivity and specificity of these tests for wildlife, and the possibility of cross-reactions with non-Brucella strains cannot be dismissed. The rose Bengal test and the tube agglutination test are considered by World Organization for Animal Health (OIE) standardized tests for diagnosing Brucella suis and Brucella abortus infection in wild animals (24). Unfortunately, there are no studies on the pathogenesis of brucellosis in wild animals and their immune response. Moreover, it is not clear how the immunoglobulins of these animals behave in such tests.

Brucellosis is considered an important infectious disease that affects public health (1). The devastation of forests, aggressive development of agriculture, increased meat production and even the tourism industry are associated with zoonosis transmission (13). Consequently, the development of surveillance programs for emerging diseases in wild animals is extremely important to avoid new cases of such infections $(1,13)$. Several diseases that affect domestic animals that have control programs are not focused on wild reservoirs, as 
the case of brucellosis in Brazil (15). Therefore, monitoring the presence of the pathogen in wildlife, and analyzing other infectious agents are necessary. Medicine conservation, sustainable agriculture, education of tourists, public health education, and risks of acquiring an exotic pet are also critical for preventing emerging diseases and new reservoirs (13).

Research on brucellosis in wild animals is scarce, especially in Brazil. Positivity by RBT must be carefully evaluated and monitored since this may represent a source of infection. The consequences are the impact on wild animal species and their role as reservoir to other animal species. Further studies involving a larger number of animals should be conducted in order to discover the impact of brucellosis in wild animals and the importance of the transmission of this disease to humans and livestock.

\section{COPYRIGHT}

(C) CEVAP 2010

\section{SUBMISSION STATUS}

Received: July 7, 2010.

Accepted: July 20, 2010.

Abstract published online: August 13, 2010.

Full paper published online: November 30, 2010.

\section{CONFLICTS OF INTEREST}

There is no conflict.

\section{ETHICS COMMITTEE APPROVAL}

The present study was approved by the Institutional Ethics and Animal Welfare Commission of the School of Veterinary Medicine and Animal Husbandry, UNESP, Botucatu Campus (ethics committee protocol n. 82/2009-CEUA) and the Brazilian Institute of Environment and Renewable Natural Resources (IBAMA n. 16900-1).

\section{CORRESPONDENCE TO}

JANE MEGID, Faculdade de Medicina Veterinária e Zootecnia, Departamento de Higiene Veterinária e Saúde Pública, UNESP, Distrito de Rubião Júnior, s/n, Botucatu, SP, 18.618-00, Brasil. Email: jane@fmvz.unesp.br.

\section{REFERENCES}

1. Zinsstag J, Schelling E, Roth F, Bonfoh B, de Savigny D, Tanner M. Human benefits of animal interventions for zoonosis control. Emerg Infect Dis. 2007;13(4):527-31.

2. Smith NH, Gordon SV, Rua-Domenech R, Clifton-Hadley RS, Hewinson RG. Bottlenecks and broomsticks: the molecular evolution of Mycobacterium bovis. Nat Rev Microbiol. 2006;4(1):670-81.

3. Bonfoh B, Wasem A, Traoré AN, Fane A, Spillmann H, Simbé CF, et al. Microbiological quality of cows' milk taken at different intervals from the udder to the selling point in Bamako (Mali). Food Control. 2003;14(7):495-500.

4. Hoeden JVD. Zoonoses. Amsterdan: Elsevier; 1964.

5. Malta MCC, Luppi MM. MarsupialiaDidelphimorphia (gambá, cuíca). In: Cubas Z, Silva JCR, Catão-Dias JL, editors. Tratado de animais selvagens - Medicina veterinária. São Paulo: Roca; 2006. p. 340-57.

6. Furtado MM, Kashivakura CK. Artiodactyla, Tayassuidae e Suidae (cateto, queixada, javali). In: Cubas ZS, Silva JCR, Catão-Dias JL, editors. Tratado de animais selvagens - Medicina veterinária. São Paulo: Roca; 2006. p. 615-29.

7. Fowler ME. Artiodactyla, Camelidae (lhama, alpaca, guanaco, vicunha). In: Cubas ZS, Silva JCR, Catão-Dias JL, editors. Tratado de animais selvagens - Medicina veterinária. São Paulo: Roca; 2006. p. 630-40.

8. Fedullo JDL. Atiodactyla, Bovidae (antílope, carneiro, cabrito selvagem). In: Cubas ZS, Silva JCR, Catão-Dias JL, editors. Tratado de animais selvagens - Medicina veterinária. São Paulo: Roca; 2006. p. 665-82.

9. Ruoppolo V. Pinnipedia (lobo-marinho, leãomarinho, foca, morsa). In: Cubas ZS, Silva JCR, Catão-Dias JL, editors. Tratado de animais selvagens - Medicina veterinária. São Paulo: Roca; 2006. p. 683-700.

10. Marigo J. Cetáceos (golfinho, baleias). In: Cubas ZS, Silva JCR, Catão-Dias JL, editors. Tratado de animais selvagens - Medicina veterinária. São Paulo: Roca; 2006. p. 715-24.

11. Moore CG, Schnurrenberger PR. Experimental infection of opossums with Brucella abortus. J Am Veter Med Assoc. 1981;179(11):1113-6.

12. Williams ES, Baker IK. Infectious diseases of wild mammals. $3^{\text {rd }}$ ed. Ames: Iowa State University Press; 2001. p. 323-31.

13. Chomel BB, Belotto A, Meslin FX. Wildlife, exotic pets, and emerging zoonoses. Emerg Infect Dis. 2007;13(1):6-11.

14. Godfroid J, Cloeckaert A, Liautard JP, Kohler S, Fretin D, Walravens K, et al. From the discovery of the Malta fever's agent to the discovery of a marine mammal reservoir, brucellosis has 
continuously been a re-emerging zoonosis. Vet Res. 2005; 36(3):313-26.

15. Lage AP, Roxo E, Muller EE, Poester FP, Cavalléro JCM, Ferreira Neto JS, et al. Programa Nacional de Controle e Erradicação da Brucelose e da Tuberculose Animal. Brasília: Ministério da Agricultura, Pecuária e Abastecimento; 2006. 188 p. Available from: http://www.agricultura. gov.br/portal/page?_pageid=33,982143\&_ dad=portal\&_schema=PORTAL.

16. Ghanem YM, El-Khodery SA, Saad AA, Abdelkader AH, Heybe A, Musse YA. Seroprevalence of camel brucellosis (Camelus dromedarius) in Somaliland. Trop Anim Health Prod. 2009;41(8):1779-86.

17. Bandyopadhyay S, Sasmal D, Dutta TK, Ghosh MK, Sarkar M, Sasmal NK, et al. Seroprevalence of brucellosis in yaks (Poephagus grunniens) in India and evaluation of protective immunity to S19 vaccine. Trop Anim Health Prod. 2009;41(4):587-92.

18. Muñoz PM, Marín CM, Monreal D, González D, Garin-Bastuji B, Díaz R, et al. Efficacy of several serological tests and antigens for diagnosis of bovine brucellosis in the presence of false-positive serological results due to Yersinia enterocolitica O:9. Clin Diagn Lab Immunol. 2005;12(1):141-51.

19. Al Dahouk S, Tomaso H, Nockler K, Neubauer $\mathrm{H}$, Frangoulidis D. Laboratory-based diagnosis of brucellosis - a review of the literature. Part II: serological tests for brucellosis. Clin Lab. 2003;49(11-12):577-89.

20. Tittarelli M, Di Ventura M, De Massis F, Petrini A, Giovannini A, Nannini D, et al. Kinetics of the antibody response in ewes experimentally infected with Brucella melitensis biovar 3. Vet Ital. 2004;40(2):5-10.

21. Deutz A, Fuchs K, Schuller W, Nowotny N, Auer $\mathrm{H}$, Aspöck H, et al. Seroepidemiological studies of zoonotic infections in hunters in southeastern Austria: prevalences, risk factors, and preventive methods. Berl Munch Tierarztl Wochenschr. 2003;116(7-8):306-11.

22. Haerer G, Nicolet J, Bacciarini L, Gottstein B, Giacometti M. Causes of death, zoonoses, and reproduction in the European brown hare in Switzerland. Schweiz Arch Tierheilkd. 2001;143(4):193-201.

23. Lucero NE, Ayala SM, Escobar GI, Jacob NR. Brucella isolated in humans and animals in Latin America from 1968 to 2006. Epidemiol Infect. 2008;136(4):496-503.

24. Bovine Brucellosis [Internet]. Version adopted by the World Assembly of Delegates of the OIE in May 2009. [cited 2010 jun 30]. Available from: http://www.oie.int/eng/normes/mmanual/2008/ pdf/2.04.03_BOVINE_BRUCELL.pdf 